\title{
KEMAMPUAN REPRESENTASI MATEMATIS SISWA DALAM MENYELESAIKAN SOAL MATEMATIKA BERBASIS HIGH ORDER THINKING SKILLS
}

\author{
Erli Ambarani, Tri Nova Hasti Yunianta \\ Universitas Kristen Satya Wacana, Jl. Diponegoro No. 52-56, Salatiga \\ E-mail: trinova.yunianta@uksw.edu
}

\begin{abstract}
Abstrak
Kemampuan representasi merupakan bagian dari lima standar pokok pada pembelajaran matematika. Kemampuan ini perlu dimiliki oleh siswa dengan baik. Menganalisis dan mendeskripsikan kemampuan representasi matematis siswa SMP dalam menyelesaikan soal matematika berbasis High Order Thingking Skills menjadi tujuan dari penelitian ini. Jenis penelitian ini adalah penelitian deskriptif kualitatif. Subjek penelitian ini berjumlah 4 siswa diambil dari 26 siswa kelas IX A SMP Negeri di kabupaten Temanggung yang memiliki kemampuan matematika tinggi. Teknik pengumpulan data penelitian ini menggunakan tes, wawancara, dokumentasi. Keabsahan data menggunakan triangulasi data. Teknik analisis data yang digunakan yaitu mereduksi data, penyajian data, dan penarikan kesimpulan. Hasil dari analisis dan deskripsi penelitian menunjukkan kemampuan representasi matematis siswa dalam menyelesaikan soal matematika berbasis HOTS berbeda beda. Kategori representasi verbal subjek S2 dan S3 dapat menggunakan representasi verbal dengan baik dan sudah memberikan kesimpulan untuk S1 belum legkap menuliskan langkah-langkahnya, dan untuk S4 belum mampu menuliskan langkah langkah pada representasi verbal. Kemampuan representasi simbolik subjek S1, S2, dan S3 masih ada kesalahan dalam menuliskan persamaan namun tidak mempengaruhi hasil, S4 pada sudah mampu menuliskan persamaan dan ekpresi dengan benar. Kategori representasi visual S1, S2, dan S4 belum mampu menggambar bangun geometri dengan lengkap sedangkan S3 salah pada menuliskan simbol pada gambar.
\end{abstract}

Kata Kunci: Analisis Deskriptif, Representasi Matematis, Keterampilan Berpikir Tingkat Tinggi

\begin{abstract}
The ability of representation is part of the five basic standards in learning mathematics. This ability needs to be possessed by students well. Analyzing and describing the representational abilities of junior high school students in solving mathematics based on Higher Order Thinking Skills is the aim of this study. This type of research is descriptive qualitative research. The subject of this study found 4 students taken from 26 students of class IX A SMP Negeri in Temanggung Regency who have high mathematical abilities. The data collection technique of this research used tests, interviews, and documentation. The validity of the data using data triangulation. The data analysis technique used is data reduction, data presentation, and conclusion drawing. The results of the analysis and research descriptions show that students' representational abilities in solving HOTS-based math problems are different. The verbal representation category of S2 and S3 subjects can use verbal representations well and has concluded that $\mathrm{S} 1$ has not yet completed the steps, and S4 has not been able to write down the steps on verbal representation. The ability of symbolic representation of subjects S1, S2, S3 still has errors in writing equations but does not affect the results, S4 already assumes equations and expressions correctly. The visual representation categories S1, S2 and S4 have not been able to draw geometric shapes completely, while $\mathrm{S} 3$ is wrong in writing symbols on the picture.
\end{abstract}

Keywords: Descriptive Analysis, Mathematical Representation, High-Order Thinking Skills 


\section{PENDAHULUAN}

Kemampuan representasi matematis merupakan bagian dari kriteria dasar yang berperanan penting dalam menumbuhkan kemampuan matematika siswa. Hal ini sejalan pada NCTM (2000) yang mencantumkan bahwa tujuan yang harus dicapai siswa ketika pembelajaran matematika di sekolah meliputi lima standar utama pada pembelajaran matematika yakni kemampuan penalaran, kemampuan komunikasi, kemampuan koneksi, kemampuan representasi, kemampuan pemecahan masalah. Alasan yang mendasarinya yaitu fasih saat melakukan translasi terhadap bentuk representasi yang berbeda, gaya guru menyampaikan ide representasi yang akan berpengaruh terhadap pemahaman siswa, dan siswa membutuhkan banyak latihan dalam membangun representasinya.

Terdapat beberapa pernyataan terkait definisi dari kemampuan representasi matematis. Huda et al (2019) menyatakan bahwa representasi matematis adalah suatu tafsiran siswa memahami masalah berupa ide yang terkonstruksi sesuai dengan pemikiran mengenai masalah serta mampu mendapatkan solusi dari permasalahan yang dikomunikasikan ke dalam bentuk fisik seperti tulisan, simbol, gambar dan benda kongkret. Pendapat lain menyatakan sebagai kemampuan yang menuntut siswa menggunakan cara lain atau metode menyajikan soal dalam cara yang baru baik secara tulisan, verbal, tabel, gambar, grafik disebut kemampuan representasi (Handayani, 2015; Ramziah, 2018). Lebih lanjut Sabirin (2014) menyatakan bahwa interpretasi siswa tentang masalah dapat membantu siswa dalam memecahkan masalah disebut representasi matematis. Berdasarkan beberapa definisi di atas, representasi merupakan salah satu usaha siswa untuk menampilkan hasil jawaban dalam bentuk gambar, ekpresi, dan tulisan.

Representasi matematis diperlukan pada proses pembelajaran di berbagai jenjang sekolah. Pernyataan tersebut sejalan dengan NCTM (2000) yang mengemukakan bahwa standar representasi pembelajaran siswa dari taman kanak kanak sampai SMA yaitu (a) mengubah, memilih, serta menerapkan representasi matematika dalam proses pemecahan masalah, (b) menggunakan dan membuat representasi untuk mengomunikasikan, mencatat, serta mengatur pemikiran matematika siswa, (c) representasi digunakan pada penafsiran dan permodelan matematika, sosial serta peristiwa fisik. Lebih lanjut Handayani (2015) mengemukakan jika kemampuan representasi mampu mempermudah dalam memahami konsep dan memecahkan masalah matematika yang tadinya sulit menjadi mudah. 
Dilain pihak, kurangnya pembelajaran matematika yang optimal di Indonesia akan menjadi kendala dalam upaya meningkatkan kualitas pendidikan dan kemajuan bangsa. Proses belajar mengajar di sekolah biasanya guru hanya memberikan materi dan cara penyelesaiannya secara langsung. Farhan \& Retnawati (2014) mengemukakan bahwa prosedur pembelajaran yang sepenuhnya proaktif (berpusat pada siswa) yang melibatkan siswa akan menunjang siswa dalam menciptakan dan menyusun ide matematikanya sendiri. Hal ini yang menyebabkan kemampuan representasi siswa sulit berkembang. Siswa hendaknya diberi kesempatan dalam bereksplorasi pada materi yang dipelajari supaya siswa menemukan sesuatu yang baru untuk mengembangkan kemampuan berpikirnya. Goldin (Rangkuti, 2014) mengemukakan bahwa representasi merupakan format yang dapat mewakili, menandakan dan menggambarkan dengan suatu cara.

Representasi matematis dapat digunakan untuk menyelesaikan soal Higher Order Thinking Skills (HOTS). Soal bertipe HOTS merupakan soal yang menekankan kemampuan berpikir tingkat tinggi serta melibatkan proses bernalar, sehingga mampu mengasah kemampuan kreatif maupun kritis (Mahmudah, 2018). Kemampuan yang berkenaan dengan penalaran, tidak hanya mengulangi, tetapiberfokus pada kemampuan analisis, memecahkan masalah, serta membuat keputusan yang benar disebut kemampuan berpikir tingkat tinggi (Sari et al, 2019). Kemampuan HOTS sangat penting untuk memecahkan masalah matematika, terutama masalah matematika tidak rutin, sehingga diperlukan kreativitas dan kemampuan berpikir kritis untuk menyelesaikan masalah tersebut (Lailly \& Wisudawati, 2015). Hal ini ditegaskan oleh Tanujaya \& Mumu (2020), yang menyatakan bahwa paling sedikit terdapat dua indikator utama dalam HOTS, yaitu keterampilan berpikir kritis dan kreatif.

Berdasarkan Taksonomi Bloom, aspek berpikir kritis meliputi ranah menganalisis dan mengevaluasi, sedangkan aspek berpikir kreatif merupakan kemampuan kognitif pada ranah mencipta. Dengan kata lain indikator dalam HOTS meliputi menganalisis, mengevaluasi, dan mencipta (Hidayati, 2017; Widana, 2017). Keterampilan berpikir kritis dan kreatif merupakan merupakan dua kemampuan yang berbeda namun saling menunjang. Berpikir kreatif mencoba mengkonstruksi sesuatu baru, sementara berpikir kritis mencoba mengevaluasi nilai yang sudah ada. Berpikir kreatif dilakukan dengan melanggar prinsip-prinsip yang diterima, sedangkan berpikir kritis dilakukan melalui penerapan dari prinsip-prinsip yang diterima (Fatmawati, et al. 2019). 
Selanjutnya, keterampilan berpikir kritis dan kreatif masih terbilang rendah di Indonesia. Hal ini dapat diamati dari prestasi Indonesia pada penilaian TIMSS tahun 2015, di mana Indonesia menduduki posisi 45 dari 50 negara. Salah satu faktor penyebabnya yaitu kurangnya siswa diberikan soal-soal yang membutuhkan penalaran dan kreativitas yang tinggi seperti TIMSS, HOTS, dan PISA (Frey, 2018). Hal ini ditegaskan oleh Destiani et al, (2017), yang menyatakan bahwa salah satu alasan buruknya capaian di Indonesia mungkin karena siswa tidak terbiasa menyelesaikan masalah PISA pada kategori HOTS. Keadaan ini terjadi karena kurang tersedianya sumber belajar matematika, seperti buku teks dan lembar kegiatan siswa (LKS) di Indonesia yang menyajikan permasalahan yang dapat dikelompokkan sebagai soal HOTS (Tanujaya \& Mumu, 2021).

Berdasarkan uraian di atas, kemampuan representasi matematis pada siswa dapat diketahui menggunakan soal-soal berbasis HOTS. Soal matematika berbasis HOTS adalah soal yang membutuhkan kemampuan berpikir kritis dan kreatif untuk menyelesaikannya. Oleh karena itu tujuan dari penelitian ini adalah menganalisis dan mendeskripsikan kemampuan representasi matematis siswa SMP dalam menyelesaikan soal matematika berbasis HOTS.

\section{METODE PENELITIAN}

Jenis penelitian yang digunakan pada penelitian ini ialah deskriptif kualitatif. Subjek dalam penelitian ini adalah siswa kelas IX A SMP Negeri kabupaten Temanggung, yang berjumlah 4 siswa dari total 26 siswa. Subjek diambil menggunakan teknik purposive sampling berdasarkan kriteria peneliti, yaitu siswa berkemampuan tinggi dipilih berdasarkan saran guru matematika dan observasi guru matematika selama proses pembelajaran matematika.

Instrumen tes, wawancara, dan dokumentasi digunakan untuk mengumpulkan data dalam penelitian ini. Subjek diujikan dengan tes berupa 4 butir soal uraian matematika berbasis HOTS materi teorema pythagoras untuk mengukur kemampuan representasi matematis siswa. Instrument tes dikembangkan dengan indikator dan bentuk operasional kemampuan representasi matematis menurut yaitu kemampuam representasi visual, simbolik, dan visual. Wawancara dilakukan secara fleksibel dan terstruktur untuk memperkuat hasil penelitian. Dokumentasi berupa jawaban siswa mengerjakan tes, 
rekaman audio wawancara subjek. Untuk memperoleh data yang valid peneliti menggunakan teknik triangulasi sumber.

Analisis data dilakukan berdasarkan prosedur Miles dan Huberman yaitu Data reduction, Data Display, Conclusion Drawing/Verification (Sugiyono, 2017). Reduksi data digunakan untuk memilah atau meringkas hal-hal yang utama dan penting. Bentuk penyajian data dalam penelitian ini adalah teks naratif atau cerita. Menarik kesimpulan berupa uraian objek untuk memperjelas objek yang diteliti. Validitas data dalam penelitian ini menggunakan triangulasi data yaitu metode pengecekan data diperoleh dengan cara melakukan pengujian, wawancara dan pencatatan data yang relevan.

\section{HASIL DAN PEMBAHASAN}

Berdasarkan hasil analisis jawaban pertanyaan dapat diketahui kemampuan representasi seseorang, dan diperkuat dengan wawancara terhadap subjek penelitian. Penelitian ini kemampuan representasi matematis yang diukur berdasarkan aspek representasi visual, representasi simbol, dan representasi verbal. Subjek terdiri dari 4 orang siswa yaitu S1, S2, S3, dan S4. Berikut merupakan hasil dari jawaban dan wawancara setiap subjek.

\section{Kemampuan Representasi Subjek S1}

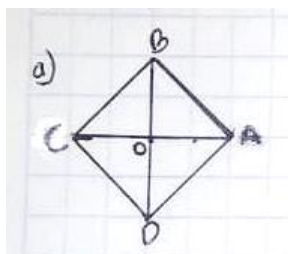

Gambar 1. Hasil Jawaban Representasi Visual Subjek S1

Untuk memperdalam analisis jawaban Subjek S1, sebagaimana tampak pada Gambar 1, berikut adalah hasil wawancara dengan subjek S1 untuk mengukur kemampuan representasi visual:

$P \quad:$ : Apa yang kamu pikirkan saat melihat soal tersebut?

S1 : Kalo Theorema Pyhtagoras itu langsung ke $c^{2}=a^{2}+b^{2}$ atau perbandingan segitiga

$P \quad:$ Informasi apa yang taat kamu dapatkan dari soal tersebut

S1 $\quad$ : Informasinya seperti guru yang menerangkan di sekolah mengenai soal perbandingan segitiga materi kelas 8 jadi sudah tau lah

$P \quad:$ Apakah bangun yang anda gambar sudah sesuai dengan informasi yang diberikan? dan jika sudah tolong dijelaskan 
S1 : Sudah bu, gambarnya kan belah ketupat ABCD dengan panjang diagonal dengan panjang diagonal $A C 10 \sqrt{3} \mathrm{~cm}$ dan besar sudut DAO 30 serta titik $O$ merupakan titik potong 2 diagonal

Berdasarkan hasil lembar jawaban dan wawancara, subjek S1 sudah mampu membuat gambar bangun-bangun geometri untuk menjelaskan masalah dan memfasilitasi penyelesaian walaupun masih sederhana dalam membuat gambar dan belum memasukan panjang garis serta besar sudut DAO yang diketahui pada soal (Gambar 2).

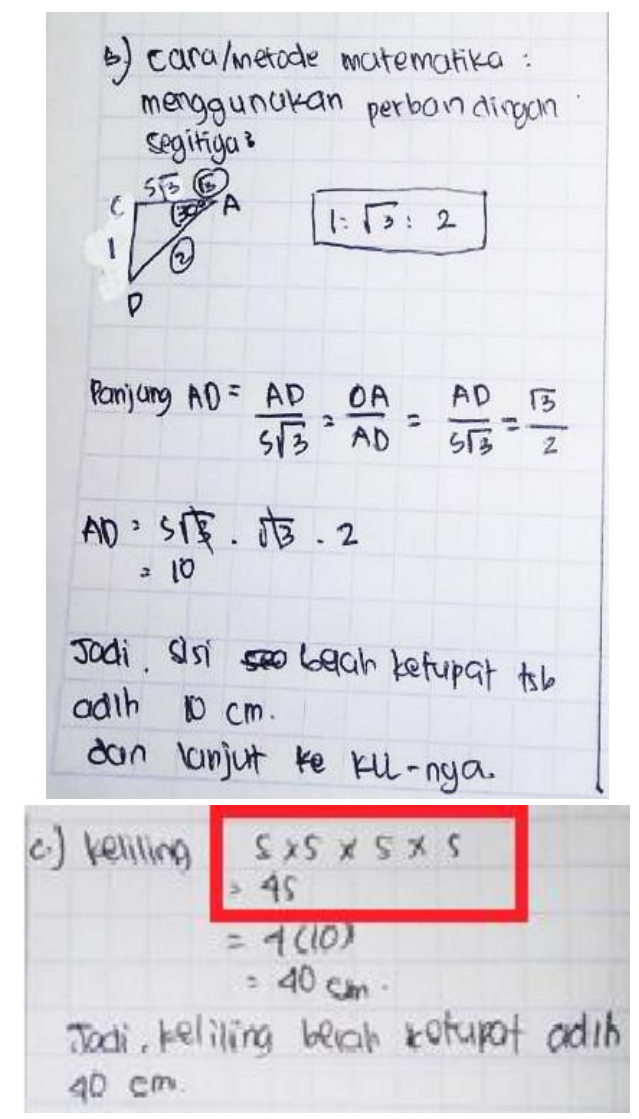

Gambar 2. Hasil jawaban Representasi Simbolik Matematika Subjek S1

Berikut hasil wawancara subjek S1 untuk mengukur representasi simbolik:

$P \quad$ : Bagaimana cara kamu membuat model matematikanya? Dari soal itu bagaimana kamu membuat model matematikannya?

S1 : Menggunakan perbandingan segitiga sih buk

$P \quad$ : Apakah cara yang kamu kerjakan merupakan cara satu satunya?

S1 : Mungkin tidak

$P \quad$ : Mungkin ada cara yang lain ya?

S1 : Iya iya bu, kan baru apa mempelajari perbandingan matematika, terus taat ingetnya yang itu doang jadi pakai yang itu aja bu, yang bisa

Berdasarkan hasil jawaban tes dan wawancara, S1 belum mampu menyelesaikan 
permasalahan pada soal menggunakan bentuk persamaan atau model matematis. Meskipun hasil akhirnya benar namun pada jawaban masih terdapat kesalahan dalam menuliskan rumus keliling belah ketupat. Hal ini dapat memicu kesalahan makna. Subjek S1 masih ragu dalam menjawab point dalam soal tersebut. disimpulkan bahwa S1 kurang mampu memenuhi indikator representasi simbolik dengan tepat.

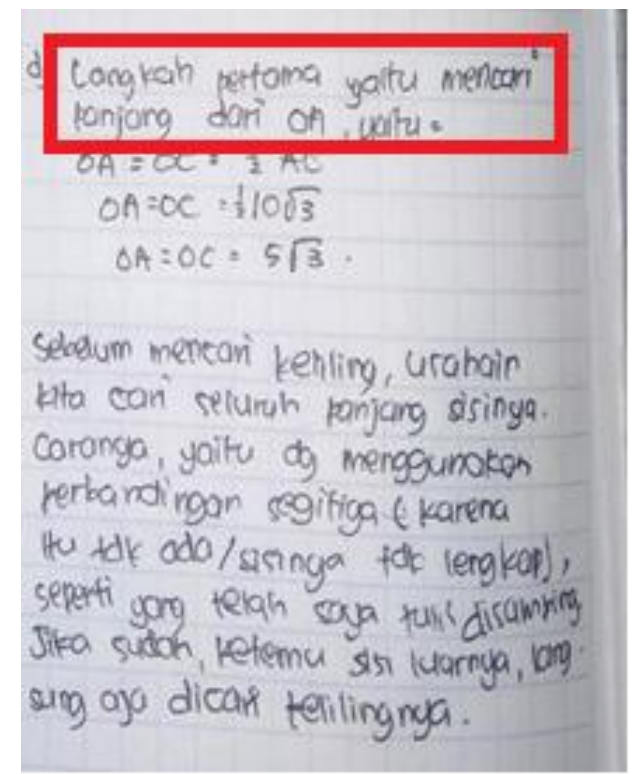

Gambar 3. Hasil Jawaban Representasi Verbal Subjek S1

S1 sudah mampu menuliskan interpretasi dari suatu representasi dengan baik. S1 sudah mampu menuliskan langkah-langkah penyelesaian dan menyusun cerita dan juga mampu menjawab soal dengan menggunakan kata kata atau teks tertulis. Namun S1 masih belum lengkap dalam menuliskan langkah awal yaitu mengambar belah ketupat terlebih dahulu seperti yang terlihat pada Gambar 3. Berikut merupakan hasil wawancara Subjek S1:

$P \quad$ : Apa yang menjadi point dalam soal tersebut?

S1 : Maksudnya point itu yang gimana bu?

$P \quad:$ Kalo kamu liat soal itu langsung oh ini itu ini, point nya apa?

S1 : Point nya itu ya sebenernya dirumus, kurang paham juga lah buk eheheh (sambil ketawa)

$P \quad$ : Dapatkah kamu menjelaskan mengapa kamu memilih penyelesaian dengan data yang diberikan?

S1 : Karena lebih mudah aja, seinget saya cuma itu

$P \quad$ :Apakah jawaban ini sudah sesuai apa yang diminta pada soal?

S1 : Alhamdulilah sudah buk 


\section{Kemapuan Representasi Subjek S2}

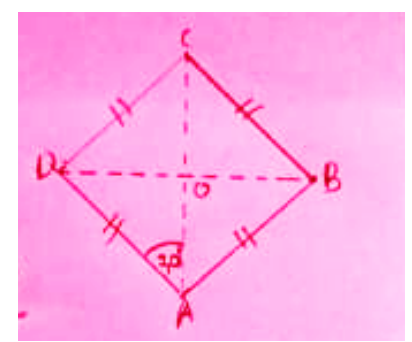

\section{Gambar 4. Hasil Jawaban Representasi Visual Subjek S2}

Berikut merupakan hasil wawancara untuk mengukur representasi visual;

$P \quad$ : Apa yang kamu pikirkan saat melihat soal terebut?

S2 : Mencari salah satu sisi yang belum diketahui untuk mencari keliling belahketupat

$P \quad$ : Informasi apa saja yang kamu dapatkan dari soal tersebut?

S2 $\quad$ : Informasi yang saya dapatkan adalah mengetahui bagaimana cara menyelesaikan soal tentang keliling belah ketupat yang salah satu sisinya tidak diketahui dengan cara menggunakan perbadingan segitiga istimewa

$P \quad$ : Apakah bangun yang kamu buat sudah sesuai dengan informasi yang diberikan?

S2 : : ya sudah karena suda sama sama menggambar belahketupat dengan panjang diagonal dengan panjang diagonal yang sama dan besar sudut yang sama yaitu 30 derajat (ragu-ragu)

Berdasarkan hasil lembar jawaban (Gambar 4) dan wawancara, Subjek S2 sudah mampu membuat gambar bangun-bangun geometri untuk menjelaskan masalah dan memfasilitasi penyelesaian walaupun belum mencantumkan panjang diagonal AC.

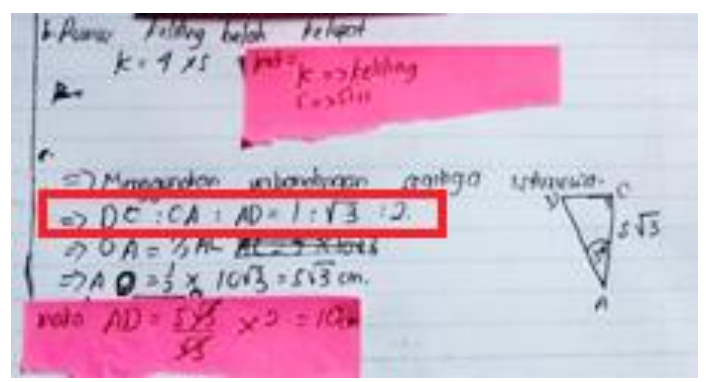

Gambar 5. Hasil jawaban Representasi Simbolik Subjek S2

Berikut merupakan hasil wawancara subjek S2 untuk mengukur representasi simbolik:

$P \quad:$ Bagaimana cara kamu memmbuat model matematikanya?

$S 2 \quad$ : yaitu dengan cara menggunakan perbandingan segitiga istimewa

$P \quad$ : Apakah cara ini merupakan cara satu satunya?

S2 : Iya

$P \quad$ : Mengapa kamu berpikiran bahwa ini benar?

S2 : Karena dengan menggunakan rumus perbandingan segiitiga istimewa saya dapat mengetahui nilai dar.... nilai panjang dari belah ketupat tersebut. 
Berdasarkan hasil jawaban tes dan wawancara pada tahap representasi ekspresi matematis, S2 tidak dapat membuat persamaan dari soal dengan benar, yaitu penulisan perbandingan segitiga yang kurang tepat seperti yang ditunjukkan pada Gambar 5 namun pada jawaban akhir memperoleh jawaban yang benar dapat disimpulkan bahwa S2 kurang mampu memenuhi indikator representasi simbolik dengan tepat.

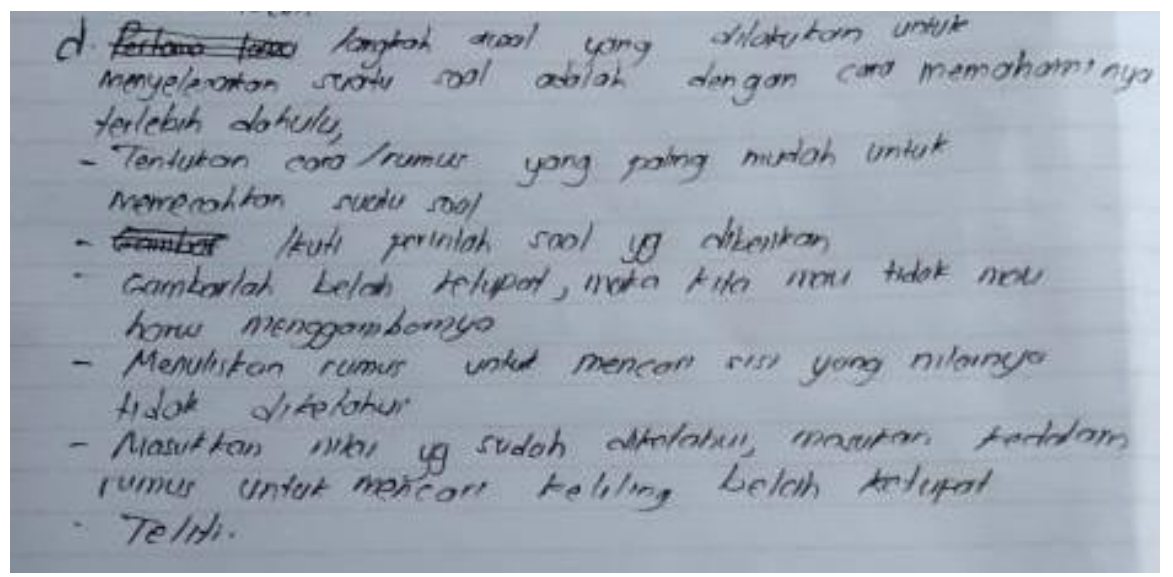

Gambar 6. Hasil Jawaban Representasi Verbal Subjek S2

Berdasarkan jawaban (Gambar 6) dan hasil wawancara, S2 mampu sudah mampu menuliskan langkah-langkah penyelesaian dan menyusun cerita dan juga mampu menjawab soal dengan menggunakan kata kata atau teks tertulis dengan lengkap namun belum terdapat kesimpulan. S2 mempunyai kepercayan diri baik menjawab soal. Berikut merupakan hasil wawancara subjek S2:

$P \quad$ : Apa yang menjadi point dalam soal tersebut?

S2 : Saya dapat menyelesaikan suatu soal yang berkaitan dengan rumus segitiga istimewa atau pun Pythagoras

$P \quad$ : Dapatkah kamu menjelaskan mengapa kamu memilih penyelesaian dengan data yang diberikan?

S2 : Karena lebih mudah dan ketemu hasilnya

$P \quad$ : Apakah jawaban ini sudah sesuai apa yang diminta pada soal?

S2 : Sudah

\section{Kemampuan Representasi Subjek S3}

Berikut hasil wawancara oleh subjek S3 untuk mengukur representasi visual:

$P \quad$ : Apa yang kamu pikirkan saat melihat soal tersebut?

S3 : yang saya pikirkan saat melihat soal tersebut adalah untuk mencari keliling belah ketupat

$P \quad$ : Informasi apa saja yang kamu dapatkan dari soal tersebut?

S3 : informasi yang saya dapatkan adalah bagaimana cara.. menghitung keliling belah ketupat menggunakan segitiga istimewa (ragu-ragu) 
$P \quad:$ Apakah bangun yang kamu buat sudah sesuai dengan informasi yang diberikan?

S3 : : Menurut saya sudah sesuai dengan soal

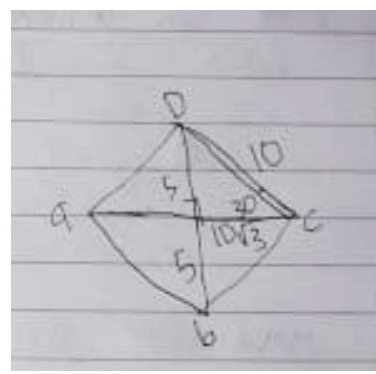

Gambar 7. Hasil jawaban Representasi Visual Subjek S3

Berdasarkan hasil lembar jawaban (Gambar 7) dan wawancara, Subjek S3 sudah mampu membuat bangun bangun geometri namun masih terdapat kesalahan dalam menuliskan apa yang diketahui pada soal. Hal ini dapat mengakibatkan kesalahan pada representasi simbolik. Maka dapat disimpulkan Subjek S3 belum mampu menyelesaikan representasi visual dengan tepat.

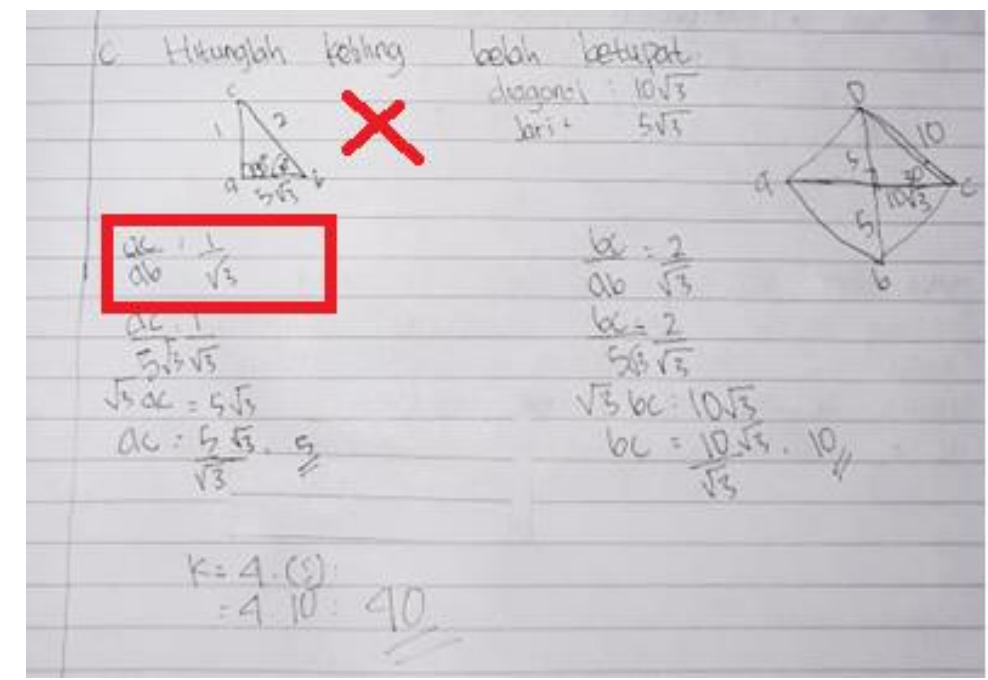

Gambar 8. Hasil Jawaban Representasi Simbolik Subjek S3

Berikut hasil wawancara S3 untuk mengukur representasi simbolik:

$P \quad:$ : Bagaimana cara kamu memmbuat model matematikanya?

S3 : Cara saya membuat model matematika dengan cara menggunakan rumus belah ketupat

$P \quad:$ : Apakah cara ini merupakan cara satu satunya?

S3 $\quad$ : saya tidak tau karena ... karena guru mengajarkan dengan cara menggunakan rumus segitiga istimewa.

Berdasarkan jawaban tes dan wawancara, S3 tidak dapat membuat persamaan atau model matematika dari soal dengan benar, yaitu penulisan perbandingan segitiga yang kurang 
tepat dan belum menuliskan satuan panjang seperti yang ditunjukkan pada Gambar 8 bahwa S3 kurang tepat dalam menuliskan simbol pada segitiga sehingga menyebabkan salah dalam perbadingan sisi segitiga namun hasil jawabannya benar dapat disimpulkan bahwa S3 belum mampu memenuhi indikator representasi simbolik dengan tepat.

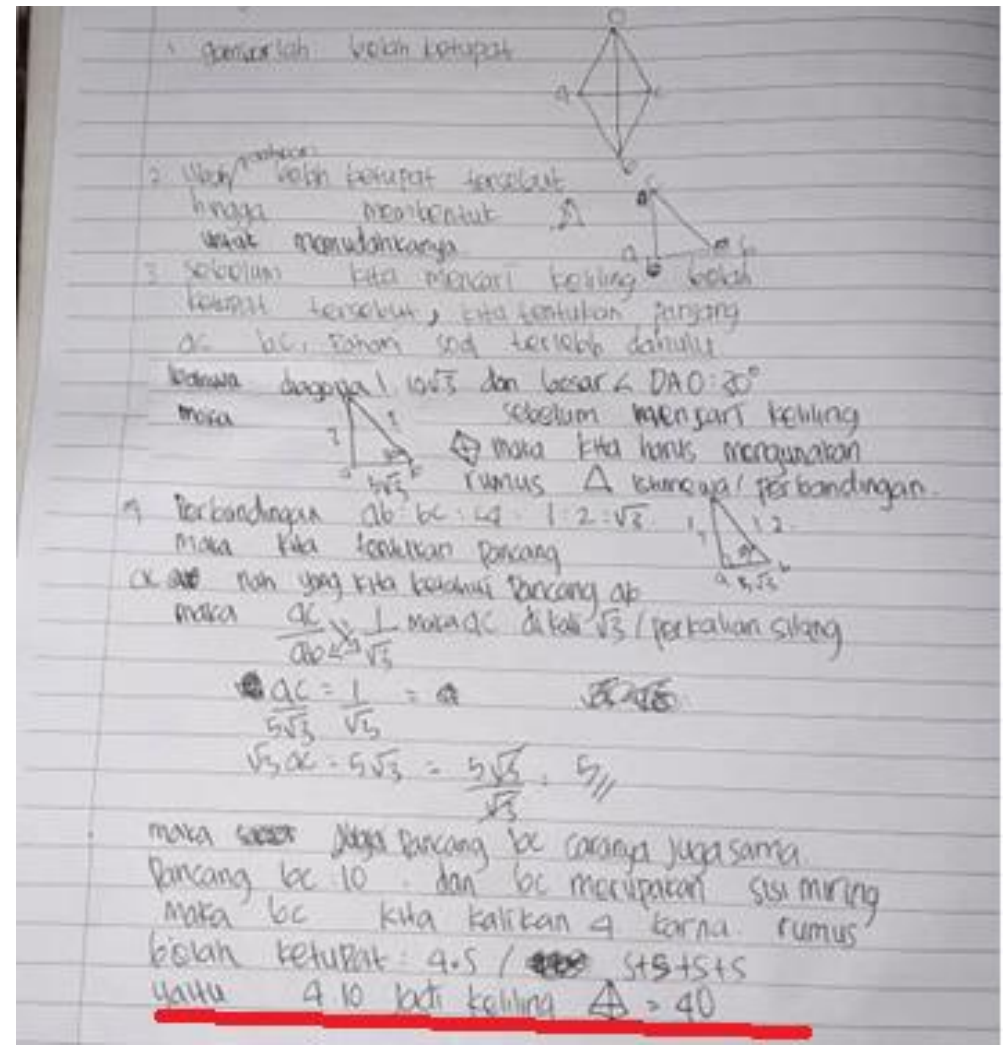

Gambar 9. Hasil Jawaban Representasi Verbal Subjek S3

Berdasarkan jawaban tes dan wawancara subjek S3 sudah mampu menyelesaikan masalah menggunakan representasi verbal. S3 sudah mampu menuliskan langkahlangkah penyelesaian dan menyusun cerita dan juga mampu menjawab soal dengan menggunakan kata kata atau teks tertulis dengan lengkap dan sudah menuliskan kesimpulan penyelesaiannya. Sebagaimana yang tertulis pada Gambar 9 dan berikut hasil wawancara:

$P \quad:$ Apa yang menjadi point dalam soal tersebut?

S3 : Point dari soal tersebut adalah menentukan keliling belah ketupat dengan diagonal AC sama dengan $10 \sqrt{3}$ besar sudut DAO sama dengan 30 derajat serta titik $O$ merupakan titik potong dua diagonal

$P \quad$ : Dapatkah kamu menjelaskan mengapa kamu memilih penyelesaian dengan data yang diberikan?

S3 : Karena menurut saya dengan menggunakan rumus tersebut penyelesaiannya lebih gampang dan tidak berbelit belit

$P \quad$ : Apakah jawaban ini sudah sesuai apa yang diminta pada soal? 


\section{Kemampuan Representasi Subjek S4}

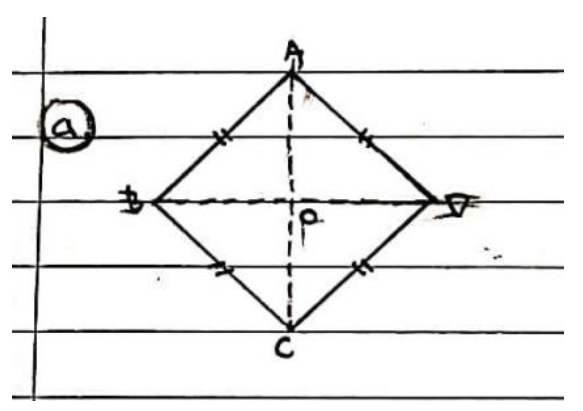

Gambar 10. Hasil Jawaban Representasi Visual Subjek S4

Berikut hasil wawancara subjek S4 untuk mengukur kemampuan representasi visual:

$P \quad$ : Apa yang kamu pikirkan saat melihat soal tersebut?

S3 : Setelah saya melihat soal tersebut saya langsung mencari jawaban dan caranya

$P \quad$ : Informasi apa saja yang kamu dapatkan dari soal tersebut?

S3 : Informasi yang saya dapatkan dari soal tersebut yaitu cara menyelesaikan segitiga tersebut dengan menggunakan rumus perbandingan dan rumus keliling segitiga

$P \quad$ : Apakah bangun yang kamu buat sudah sesuai dengan informasi yang diberikan?

S3 : Saya rasa sudah sesuai dengan informasi yang diberikan

Berdasarkan hasil lembar jawaban (Gambar 10) dan wawancara oleh subjek S4 sudah mampu membuat gambar bangun-bangun geometri untuk menjelaskan masalah dan memfasilitasi penyelesaian walaupun masih sederhana dalam membuat gambar dan belum memasukan panjang garis serta besar sudut DAO yang diketahui pada soal

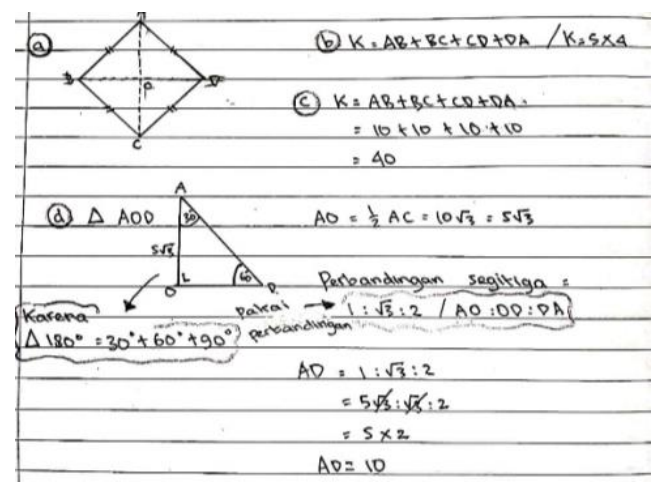

Gambar 11. Hasil Jawaban Representasi Simbolik Subjek S4

Berikut merupakan hasil wawancara subjek S4 untuk mengukur representasi simbolik

$P \quad$ : Bagaimana cara kamu memmbuat model matematikanya?

S4 : Dengan cara mencari atau mengetahui dulu sudut-sudutnya dan setelah itu menggunakan perbandingan segitiga yang sesuai dengan sudut sudut tersebutsetelah itu masukan sisi-sisi bangun segitiga yang diinformasikan soal tersebut dan yang 
Berdasarkan hasil jawaban tes (Gambar 11) dan wawancara, S4 sudah mampu menyelesaikan permasalahan pada soal menggunakan bentuk persamaan atau model matematis dengan baik. Menuliskan perbandingan segitiga dengan benar, disimpulkan bahwa S4 sudah mampu memenuhi indikator representasi simbolik dengan tepat.

Berdasarkan jawaban tes dan wawancara subjek S4 belum mampu menyelesaikan masalah menggunakan representasi verbal. S4 belum menuliskan langkah-langkah penyelesaian dan menyusun cerita pada lembar jawaban. Namun pada tahap wawancara S4 mampu menjawab point pada soal. Berikut merupakan hasil wawancara:

$P \quad$ : Apa yang menjadi point dalam soal tersebut?

$S 4$ : point nya yaitu dengan menggunakan rumus keliling segitiga, perbandingan segitiga dan cara menyelesaikan soal tersebut.

$P \quad$ : Dapatkah kamu menjelaskan mengapa kamu memilih penyelesaian dengan data yang diberikan?

S4 : Karena dengan menggunakan penyelesaian tersebut akan lebih jelas dan paham.

$P \quad$ : Apakah jawaban ini sudah sesuai apa yang diminta pada soal?

S4 : Sudah

Analisis deskripsi dari jawaban siswa di atas diperoleh temuan setiap siswa memiliki kemampuan representasi matematis berbeda beda dalam menyelesaikan soal berbasis HOTS. Berdasarkan penelitian sebelumnya menunjukkan bahwa jika sejumlah individu yang berbeda diberikan permasalahan yang sama maka hasil dan kemampuan representasi matematisnya akan berbeda (Deswantari dkk., 2020). Selain itu juga terdapat kesalahan pada menyelesaikan soal sehingga menghasilkan kemampuan representasi matematis yang berbeda. sejalan dengan penelitian yang dilakukan oleh Panduwinata, (2019) mengemukakan penyebab perbedaan kemampuan representasi adalah sebagian siswa hanya mampu menguasai kurang dari tiga indikator kemampuan representasi siswa, bahkan ada yang bisa menguasai semua indikatornya. Ditemukan fakta bahwa keempat subjek sama sama menggunakan rumus perbandingan segitiga untuk menyelesaikan permasalahan.

Representasi visual diukur dengan indikator siswa dapat membuat gambar bangun geometri untuk memperjelas masalah dan memfasilitasi penyelesaiannya dari soal. 
Subjek S1, S2, dan S4 belum lengkap menuliskan apa yang diketahui pada soal, sedangkan S3 masih salah menuliskan apa yang diketahui dari soal sehingga berpengaruh pada penentuan model matematikanya. Hasil penelitian Mulyaningsih et al, (2020) menyatakan bahwa secara keseluruhan pada kategori tinggi belum mampu memenuhi indikator representasi gambar karena ketidaktepatan dalam menyajikan representasi gambar. Seperti halnya dengan penelitian Suganda (2015) bahwa kesulitan dalam merepresentasikan suatu permasalahan ke bentuk representasi gambar dikarenakan siswa kurang pemahaman dalam berbagai konsep.

Representasi simbolik persamaan atau ekspresi diukur dengan indicator: membuat persamaan atau model matematis dari soal yang tersedia; dan menyelesaikan masalah dalam menyelesaikan soal HOTS materi teorema Pythagoras dengan melibatkan ekspresi matematis. Keempat subjek memiliki kesamaan yaitu menggunakan rumus perbandingan segitiga untuk mencari keliling belah ketupat dan bisa memperoleh hasil dengan benar dan sangat percaya diri. S4 sudah bisa menggunakan representasi simbolik dengan benar, sedanhkan subjek S1, S2, S3 kurang teliti dan keliru dalam menuliskan simbol namun tidak mempengaruhi hasil. Hal ini bersesuaian dengan penelitian Hijriani, Rahardjo, \& Rahardi, (2018), yang menyatakan bahwa alasan siswa kurang bisa mengkonstruksi verbal dan simbolik dengan tepat adalah disebabkan karena siswa kurang teliti. Selanjutnya Triono (2017) mengemukakan bahwa kurangnya pemahaman terhadap variabel menyebabkan kesalahan sswa menggunakan simbol matematika dalam model matematika.

Secara keseluruhan siswa sudah mampu menuliskan representasi verbal dengan baik namun masih ada siswa yang belum menuliskan representasi verbal. Representasi verbal diukur berdasarkan indikator yaitu menuliskan langkah langkah penyelesaian masalah matematika dengan kata kata. Siswa S2 dan S3 sudah menuliskan langkah langkahnya dengan benar serta terdapat kesimpulan, S1 sudah menuliskan langkah langkah penyelesaian namun belum lengkap, sedangkan S4 belum menuliskan langkah langkah penyelesaian dengan kata kata, namun setelah melakukan siswa mampu menjelaskan langkah langkah penyelesaianya dan belum diberikan kesimpulan. Menurut penelitian Adabiah, (2018) yang menyatakan bahwa beberapa siswa yang tidak dapat menuliskan kesimpulan pada jawaban yang benar, maka masih banyak siswa yang tidak memenuhi indikator representasi verbal. 


\section{KESIMPULAN}

Terdapat tiga kemampuan representasi siswa, yaitu representasi verbal, representasi simbolik, dan representasi visual. Setiap iswa memiliki kemampuan representasi matematis dalam menyelesaikan soal matematika berbasis HOTS yang berbeda beda. Setiap siswa memiliki kelemahan dan kelebihan pada kemampuan representasi yang berbeda. Pada kategori yang sama dan masalah yang sama, siswa memiliki kemampuan representasi matematis yang berbeda.

\section{DAFTAR PUSTAKA}

Adabiah, R. (2018). Analisis Kemampuan Representasi Matematis Siswa dalam Menyelesaikan Soal Segi Empat di Mts NW Dasan Tapen Gerung Lombok Barat. Skripsi, Universitas Islam Negeri Mataram.

Aliyanti, A. P., \& Putri, O. R. U. (2019). Analisis Kesalahan Representasi Simbolik Mahasiswa Dalam Menyelesaikan Soal High Order Thinking Skill. AKSIOMA: Jurnal Program Studi Pendidikan Matematika, 8(3), 382-394.

Destiani, D., Ismet, I., \& Wiyono, K. (2017). Pengembangan Bahan Ajar IPA Berorientasi Framework Science PISA untuk Sekolah Menengah Pertama. Prosiding Seminar Nasional Pendidikan IPA 2017 STEM untuk Pembelajaran SAINS Abad, 21, 654663.

Deswantari, E., Setyadi, D., \& Mampouw, H. L. (2020). Representasi Matematis Siswa dalam Memecahkan Masalah Matematika Materi Poligon. Jurnal Pendidikan Matematika Raflesia, 5(1), 46-62.

Fatmawati, A., Zubaidah, S., Mahanal, S., \& Sutopo. (2019). Critical Thinking, Creative Thinking, and Learning Achievement: How They are Related. Journal of Physics: Conference Series, 1417(1), 012070.

Frey, B. B. (2018). Timss. The SAGE Encyclopedia of Educational Research, Measurement, and Evaluation. https://doi.org/10.4135/9781506326139.n704

Handayani, H. (2015). Pengaruh Pembelajaran Kontekstual Terhadap Kemampuan Pemahaman Dan Representasi Matematis Siswa Sekolah Dasar. Didaktik: Jurnal Ilmiah PGSD STKIP Subang, 1(1), 142-149. https://doi.org/10.36989/didaktik.v1i1.20

Hidayati, A. U. (2017). Melatih Keterampilan Berpikir Tingkat Tinggi dalam Pembelajaran Matematika pada Siswa Sekolah Dasar. Terampil: Jurnal Pendidikan dan Pembelajaran Dasar, 4(20), 143-156.

Hijriani, L., Rahardjo, S., \& Rahardi, R. (2018). Deskripsi Representasi Matematis Siswa SMP dalam Menyelesaikan Soal PISA. Jurnal Pendidikan: Teori, Penelitian, dan Pengembangan, 3(5), 603-607. 
Huda, U., Musdi, E., \& Nari, N. (2019). Analisis Kemampuan Representasi Matematis Siswa Dalam Menyelesaikan Soal Pemecahan Masalah Matematika. Ta'dib, 22(1), 19. https://doi.org/10.31958/jt.v22i1.1226

Lailly, N. R., \& Wisudawati, A. W. (2015). Analisis Soal Tipe Higher Order Thinking Skill ( HOTS ) dalam Soal UN Kimia SMA Rayon B Tahun 2012 / 2013. Kaunia, 11(1), 27-39.

Mahmudah, W. (2018). Analisis Kesalahan Siswa dalam Menyelesaikan Soal Matematika Bertipe HOTS Berdasar Teori Newman. Jurnal UJMC, 4(1), 49-56.

Mulyaningsih, S., Marlina, R., \& Effendi, K.N.S. (2020). Analisis Kemampuan Representasi Matematis Siswa SMP dalam Menyelesaikan Soal Matematika. JKPM: Jurnal Kajian Pendidikan Matematika, 6(1): 99-110

NCTM. (2000). Principles and Standards for School Mathematics. USA: Association Drive, Reston.

Panduwinata, B., Tuzzahra, R., Berlinda, K., \& Widada, W. (2019). Analisis Kesulitan Representasi Matematika Siswa Kelas VII Sekolah Menengah Pertama pada Materi Sistem Persamaan Linier Satu Variabel. Jurnal Pendidikan Matematika Raflesia, 4(2), 202-210.

Ramziah, S. (2018). Peningkatan Kemampuan Representasi Matematis Siswa Kelas X2 SMAN 1 Gedung Meneng Menggunakan Bahan Ajar Matriks Berbasis Pendekatan Saintifik. Mosharafa: Jurnal Pendidikan Matematika, 5(2), 138-147. https://doi.org/10.31980/mosharafa.v5i2.269

Sabirin, M. (2014). Representasi dalam Pembelajaran Matematika. Jurnal Pendidikan Matematika, 1(2), 33. https://doi.org/10.18592/jpm.v1i2.49

Sari, Y., Cahyaningtyas, A. P., Maharani, M. M., Yustiana, S., \& Kusumadewi, R. F. (2019). Meningkatkan kemampuan menyusun soal IPA berorientasi HOTS bagi guru Sekolah Dasar Gugus Pandanaran Dabin IV UPTD Semarang Tengah. Indonesian Journal of Community Services, 1(2), 175. https://doi.org/10.30659/ijocs.1.2.175-183

Suganda, V. A. (2015). Kesuitan Merepresentasikan Soal Pemecahan Masalah Matematika pada Siswa di Sekolah Dasar. Jurnal Kajian Pengembangan Pendidikan, 2(1), 41-47.

Sugiyono. (2017). Metode Penelitian Kualitatif. Bandung: Alfabeta.

Tanujaya, B., \& Mumu, J. (2020). Students' Misconception of HOTS Problems in Teaching and Learning of Mathematics, Journal of Physics: Conference Series, 1657 (1) 012081

Tanujaya, B., \& Mumu, J. (2021). Reconstruction of HOTS Problems Based on Questions in Mathematics Textbook, Journal of Physics: Conference Series, 1832 (1) 012052 Triono, A. (2017). Analisis Kemampuan Representasi Matematis Siswa Kelas VIII SMP Negeri 3 Tangerang Selatan. Skripsi Universitas Islam Negeri Syarif Hidayatullah. 